CHAPTER 9 FROM STAGING HISTORY: ESSAYS IN LATE MEDIEVAL AND HUMANIST DRAMA, EDS PETER HAPPÉ AND Wim HÜSKEN (LEIDEN:BRILL, 20201)

\title{
Helvetic Henry? A Swiss Adaptation of Henry V, or Something Near Enough
}

\author{
Elisabeth Dutton
}

\begin{abstract}
This article describes the processes of translation, cutting and rearrangement by which Shakespeare's Henry $V$, a play often identified with 'Britishness', is adapted for a modern Swiss audience. As a play celebrating a national 'hero' and a military history largely unknown to the Swiss, Henry $V$ is adapted to an exploration of political power in the abstract, in particular the political power of rhetoric which Shakespeare's Henry exemplifies and which can be richly presented using the multiple languages and dialects of Switzerland. Like the adaptation by Swiss writer Friedrich Dürrenmatt of Shakespeare's Titus Andronicus, the translation not just of words but also of context occasions a certain black humour by which the subversive aspects of Shakespeare's text are foregrounded and accentuated, and any sense of heroism stripped away. In particular, Shakespeare's parodic presentation of the French army is pushed to absurdity in order to highlight the rhetorical construction of 'the enemy'. The essay explores the influence of geography on the use of history in drama, and brings the arguments of other essays in this volume up to the present day, suggesting why the topic of dramatized history continues to be important.
\end{abstract}

\section{Keywords}

William Shakespeare, Henry V, Switzerland, The Swiss Stage Bards, Battle of Agincourt, Friedrich Dürrenmatt, George Chapman, multilingualism, translating Shakespeare

\section{Introduction}

In October 2015, the United Kingdom marked the $600^{\text {th }}$ anniversary of the Battle of Agincourt, in which an English army led by Henry V defeated French King Charles VI's much greater force, with a series of exhibitions 
and events including a banquet at the Guildhall and a service at Westminster Abbey. ${ }^{1}$ Comment on these commemorations was often complacently aware of the remoteness of history - Harry Mount in the Telegraph, for example, telling us, on 23 October 2015: "The closest restaurant to the hallowed battlefield of Agincourt is the Restaurant Charles VI [where] even patriotic Englishmen will enjoy the $€ 18$ (£13) set meal; my duck and smoked salmon were extremely good."2 But some comment was more troubled. Ed West, writing in the Catholic Herald, characterised Agincourt as part of "a spurious war of aggression carried out by one of the worst monsters in English history," Henry V, who "left behind nothing but corpses and grieving mothers". ${ }^{3}$ West notes, among other atrocities, the massacre of French prisoners ordered by Henry - a slaughter which, even if explained as a military precaution within an English triumph against overwhelming odds, casts a long shadow over a battle that was also part of an opportunist invasion. West, therefore, wonders "why this is worth celebrating, except as a way of expressing our appreciation of the Bard."

Certainly, the Bard featured prominently in the anniversary events. "A Concert of Agincourt Music and Readings" at All Hallows by the Tower included scenes from his Henry $V$ and other readings by Esmond Knight, who played Fluellen in Olivier's film of Shakespeare's play. At the Guildhall banquet, there were recitations, including the St Crispin's Day Speech, by Sam Marks from the Royal Shakespeare Company's production of Henry V. At Westminster Abbey, actor and noted longbow expert Sir Robert Hardy performed passages of Shakespeare's play. Although for military historians the victory of an outnumbered English and Welsh army at Agincourt was a matter of weaponry, tactics, and the weather, in the popular imagination Agincourt is the triumph of the Englishman, the Welshman and the Scotsman, fighting together and urged on by the rhetoric of their charismatic young king: the 'band of brothers', the 'happy few'; arguably it was not Agincourt 1415, but Shakespeare's Henry $V$, a play written in 1599, that, indirectly, was commemorated in $2015 .^{4}$

The 2015 events are documented at https://www.futurelearn.com/courses/agincourt/0/steps/15340 https://www.telegraph.co.uk/travel/destinations/europe/france/nord-pas-de-

calais/articles/Agincourt-600th-anniversary-A-return-to-the-muddy-battlefield-where-Henry-Vtriumphed/

3 https://catholicherald.co.uk/commentandblogs/2015/10/23/agincourt-is-nothing-to-celebrate/

4 That Shakespeare's myth transforms historical 'fact' in the collective memory exemplifies Gevert G. Nöretemann's thesis, quoted at the beginning of Elsa Strietman's essay in this volume, that history becomes myth that serve's 'the group's self-definition.' 
Shakespeare's play tells the story of the young English king Henry V, who, with the support of the Church and on the basis of an ambiguous claim to the French throne, invades France. With an army of Scottish, Welsh, and English soldiers, he advances through France and wins a major victory, against a much larger French army, at Agincourt. Hearing that the French have killed English non-combatant boys, Henry orders the slaughter of French prisoners. He then woos the French princess, Katherine, and marries her as part of a settlement that recognises him as heir to the French throne. The play featured explicitly on the United Kingdom's national scene three years before the Agincourt commemorations, as part of the cultural programme that accompanied the 2012 Olympics. The Globe Theatre's use of Henry $V$ as the climax of its 2012 "Globe to Globe" season was much commented on: the play was chosen for presentation by an English company, in English, when the other works were presented by actors from many different nations in a range of different national languages. In a festival that celebrated internationalism, the nationalism of Henry $V$ and its mocking presentation of non-English characters as culturally and linguistically inferior seems at best tactless. ${ }^{5}$ In the same year appeared Thea Sharrock's small screen adaptation of Shakespeare's play, starring Tom Hiddleston, as part of the Hollow Crown series. Henry $V$ had of course already been twice adapted for the big screen: in Laurence Olivier's patriotic film of 1944, and in Kenneth Branagh's de-glamorised, gritty but nonetheless ambiguous post-Falklands version of 1989.

As discussion of these films reveals, the play has become a statement about 'Britishness', or perhaps 'Englishness'. ${ }^{6}$ But, although Shakespeare may sometimes seem to offer the 'common cultural currency in the heritage and the consciousness of Western Europe' that Elsa Strietman argues the Dutch rhetoricians found in scripture, ${ }^{7}$ not all his plays are equally

\footnotetext{
5 For tempered accounts of the production's presentation of nationalism and the figure of Henry, see Stephen Purcell, "Shakespeare, Spectatorship, and the 'Olympic Spirit'," in Shakespeare on the Global Stage: Performance and Festivity in the Olympic Year, eds. Paul Prescott \& Eric Sullivan (London: Bloomsbury Arden Shakespeare, 2015), 133-62, and Abigail Rokison, “'From thence to England': Henry $V$ at Shakespeare's Globe," in Shakespeare Beyond English: A Global Experiment, eds. Susan Bennett \& Christie Carson (Cambridge: Cambridge University Press, 2013), 303-07.

6 On Branagh's use of Vietnam war movie codes and the tensions between his images and music, see Maurice Hindle, Studying Shakespeare on Film (Basingstoke: Palgrave Macmillan, 2007), 147-51. On Branagh's film as a struggle with Olivier's, see Peter S. Donaldson, "Taking on Shakespeare: Kenneth Branagh's Henry V," Shakespeare Quarterly 42 (1991): 60-71.

Elsa Strietman, " "An easy commerce of the old and new": Rhetoricians and the Use of the Past', in the present volume, 169.
} 
internationally known, and Henry $V$ does not appear to be very important to anyone apart from the British. This may be because the histories are generally much less performed than the tragedies and comedies outside the United Kingdom: for example, from September 2016 to January 2017, the German Shakespeare Society lists sixty-one premieres of productions (including theatre, opera and dance) of or based on Shakespeare plays; only two were productions of history plays - a Richard III in Hamburg and a twopart project, in Freiburg im Breisgau, which condensed all the history plays into a theatrical sequence dealing with the struggle for power and the political and theatrical enactment of violence. ${ }^{8}$ Of course, whereas in Britain the histories offer a dramatization of national history, in Germany they do not. But there may be additional reasons for the European neglect of Henry $V$ in particular. In France, Jean-Michel Déprats reports that Henry $V$ was not performed in French until 1999, and not just because of indignation at the play's disparaging treatment of the French military: "French directors shirk from staging Henry $V$ because of its dominant heroic notes and jingoistic politics." Today's directors want their Shakespeare "disillusioned" with "the violence of history", and are therefore troubled by Henry $V$, which "can be judged as less dialectic and ambiguous" than the other history plays. ${ }^{9}$

In fact, the British, too, are troubled by Henry $V$. The play has not only been repeatedly revived in times of national crisis, but has also been 'consistently rewritten' on those occasions. "When patriotism wants a play, the play Shakespeare produced - for just such an occasion - is found insufficiently simple and unnecessarily disquieting". ${ }^{10}$ The play was first staged in 1599 yet the 1600 Quarto edition already omits much that complicates audience understanding of its action and its protagonist: as Gary Taylor notes, it is always "the more serious scenes" that "suffer the most drastic surgery". ${ }^{11}$ The 1600 Quarto cuts Shakespeare's opening scene, and lines in the second scene, that show clerical machinations behind ecclesiastical support for Henry's claim to the French throne; thus it reduces the evidence that Shakespeare apparently provided to undermine arguments about Henry's right to invade France. It also cuts much of

8 See listings made available by the Deutsche Shakespeare Gesellschaft (German Shakespeare Society), http://shakespeare-gesellschaft.de/theater/premieren-spielzeit-201617.html. Accessed June 13, 2017.

9 Jean-Michel Déprats, "A French history of Henry V," in Shakespeare's History Plays: Performance, Translation, and Adaptation in Britain and Abroad, ed. Ton Hoenselaars (Cambridge: Cambridge University Press, 2004), 75.

10 William Shakespeare, Henry V, ed. Gary Taylor (Oxford: Clarendon Press, 1982), 11.

11 Ibid. 
Henry's violent speech to the Governor of Harfleur in scene 3.3, a change which must surely have allowed for a gentler, less savage presentation of the protagonist.

\section{Shakespeare and Swiss History}

The Swiss Henry $V$ described here thus breaks the play's tradition of 'Britishness' while at the same time continuing its tradition of adaptation to the shifting political ideals of the historical moments at which it is performed. The production, by the Swiss Stage Bards, was billed as Shakespeare's Henry V (sort of) /mehr oder weniger / plus ou moins and was staged in November-December 2018 at various locations around the city of Fribourg: the Centre Fris, the Gallery Fri-Art, and the Gutenberg Museum.

The Swiss Stage Bards began their Multilingual Shakespeare project at the officially French-German bilingual University of Fribourg: they produce 'Swiss Shakespeare' that exploits the diverse linguistic resources of a tiny country that, located at the heart of Europe, has four official national tongues and numerous dialects as well as a rich array of languages brought by immigrants. The script of the Helvetic Henry $V$ united German and French, as well as Italian, but the play was not just translated; it was also historically and geographically re-contextualized. ${ }^{12}$ This 'translation', etymologically a 'carrying across', not just of language but also of context, is similar to the 1970 translation, by Swiss playwright Dürrenmatt, of Shakespeare's Titus Andronicus: Dürrenmatt left the overt setting of his fictional text unchanged, presenting the action as historically and geographically removed, but created characters whose sensibilities and verbal styles betray an unmistakable contemporaneity, giving rise to an absurd feeling of dissonance. As Lukas Erne discusses, Dürrenmatt translated Shakespeare's tragedy into black comedy, and did so in order to illustrate one main point: the futility of patriotism. This was, in Dürrenmatt's view, the important message of history, whether fictionalised, like Titus Andronicus, or recent and real: World War II had demonstrated the dangers of ideologies of the 'fatherland', and neither the Swiss political establishment, which argued in the years after the war that their skilful politics and the deterrent powers of the Swiss army had saved the country from German invasion, nor the anti-establishment, which accused the Swiss government of collaboration with the Nazis, had properly understood this

12 So far this adaptation has not yet been published but an online edition of it may appear in the near future. Quotes from this play in the current essay are from its typescript. 
message. Dürrenmatt therefore adapted Titus to focus not on the protagonist's loss of his family (it is particularly noticeable that his mutilated daughter Lavinia, pre-eminent symbol of suffering in Shakespeare's play, barely features), but on his loss of belief in justice and fatherland. Dürrenmatt thus "arguably tries to legitimate the views his play advances ... by means of the label 'Shakespeare'", while his adaptation remains an example of "fascinating misreadings of the Shakespearean original that are profoundly and inevitably local". ${ }^{13}$ Similarly, the Swiss Henry $V$ is full of deliberate 'misreadings' that facilitate the translation of Shakespeare's history not only into languages that are, in some cases, international, but in Switzerland are caught up in a series of esoteric relationships, but also into a localised political context informed by Swiss history.

Switzerland's 'national' history is very different from that of France or England; it has not long been a nation state. The Swiss in Shakespeare are mercenaries, fighting for money, not nationhood. Switzerland's famous - or perhaps infamous - neutrality during the Second World War moves the Swiss Henry $V$ impossibly far from Olivier's patriotic film adaptation: as Dürrenmatt recognised, for a country that is tiny and sandwiched between the big, and historically belligerent, European countries, Germany and France, "In unworthy times, an entirely worthy attitude is impossible," and "Politicians cannot be expected to be heroic." 14 There is thus an additional irony: the Switzers, known in Shakespeare's day for their ferocity as soldiers, have now become a by-word for not fighting, for neutrality. Neutrality is an ongoing official policy in international affairs: the Swiss have not sent fighters to any of the recent international conflicts, although they are involved in peace-keeping - for example, Swiss soldiers guard the border between North and South Korea. The continuing high visibility of the Swiss army in the international imagination is perhaps mostly to do with pen-knives; in daily Swiss life, the army is visible because military service is compulsory for all Swiss men - students often have to excuse themselves from class because of it. However, the army is conceived nonaggressively as a home guard, and the Swiss air force, notoriously, operate only in office hours. ${ }^{15}$

13 Lukas Erne, “Lamentable comedy or black tragedy?: Friedrich Dürrenmatt's adaptation of Titus Andronicus", in World-wide Shakespeares: Local appropriations in film and performance, ed. Sonia Massai (London-New York: Routledge, 2005), 94.

14 Dürrenmatt, cited by Erne, "Lamentable comedy," 93.

15 This was revealed amid much ridicule in 2014. The army, that guardian of traditionally masculine behaviour patterns, reacted by announcing that the air force would operate around the clock by 2018 or 2020, at an additional cost of around 25 million Euros per year. 
But there is an important connection between Shakespeare's Henry and Swiss History - a sense of the importance of language. Shakespeare's play is highly engaged with language, for example imaging the French Princess learning English so she can talk to Henry, or showing Henry's manipulation of language in his call to arms, which uses only Anglo-Saxon words, with no French loans. ${ }^{16}$ Indeed, in Shakespeare's play it is Henry's skill with language that enables him to inspire his audiences as well as his soldiers. The Swiss adaptation of Henry $V$ therefore concentrated on this theme, creating a Henry who could say whatever people needed to hear, in whatever language they needed to hear it. Furthermore the tribal rivalries, echoed in dialect, of the Englishman, the Welshman and the Scotsman that Shakespeare's play explores in the ranks of Henry's army were echoed in the linguistic rivalries of the Swiss national languages - French, German, Italian. ${ }^{17}$

Like the film adaptations and the 1600 Quarto, the translators of Swiss Henry $V$ were troubled by scenes in which the Church legitimises Henry's war, and by the historical fact, presented in Shakespeare's play, that Henry ordered the killing of prisoners on the battlefield. The strategy for dealing with these difficulties lay in a consideration of the production's target audience: since the Swiss have never had a king, Henry as 'king' is immediately alien to a Swiss audience even as he is, doctrinally at least, the embodiment of their own nation to a British audience. The Church as validating kingly power is also, of course, alien to Switzerland, and indeed there is no unifying Swiss Church, the confessional diversity and independence of the Swiss Cantons having been an essential aspect of Swiss history for centuries. Swiss Shakespeare assumes that, while there may be a Helvetic consciousness of, say, Hamlet, there is not yet a Helvetic Henry V, and that translation must therefore be pragmatically radical: no kings, no priests nor Church, indeed no lineage of 'fifthness'. There is, consequently, no drive to idealise Henry.

\section{$3 \quad$ Language and Power}

Paradoxically, in creating a Swiss Henry $V$, Swiss Shakespeare creates a $H e n r y V$ for all nations and none: the adaptation moves beyond international wars and exposes the drive to power in which 'nations' are simply

16 David Steinsaltz, "The Politics of French Language in Shakespeare's History Plays," Studies in English Literature 1500-1900 42 (2002): 317-34.

17 We were unable to find an actor to perform in Rumansch, the fourth national language, but the Hostess spoke a few words of Rumansch in the opening scene. 
particularly convenient concepts by which to manipulate others.

Dürenmatt's presentation of the futility of patriotism is thus reinforced and developed, in a creative tension with the impulse of many dramatized histories, as discussed by Wim Hüsken, to seek 'the germ of a sense of national identity.' 18 The first two scenes of Shakespeare's Henry $V$, from the conversation between Canterbury and Ely to Henry's solemn declaration of his intention to go to war, can easily be read as a portrait of power politics and of interest groups vying for access to and influence over the nation's power-centre. The first act suggests that there are crucial decisions to be taken, and that the course of policy is truly open and up for debate; but politics in the rest of the play is largely focused on Henry's skilled implementation of the decisions - military, diplomatic, and domestic taken at the outset. In these opening scenes, then, casting Henry as a political leader presiding over a cabinet meeting does no great violence to Shakespeare's original. The arguments presented sound remarkably familiar to a modern reader: war is a means to unite the nation (1.2.115$35),{ }^{19}$ but also a potential risk to internal security (1.2.136-83); interest groups offer monetary incentives "for mitigation of this bill / Urged by the Commons" (1.1.71-72) by adopting a militarised foreign policy (1.1.76-82, 1.2.132-35), and eventually the provocative outsider appears - in this case, an ambassador from the Dauphin, who is not even the declared enemy's main political leader and could therefore in principle be ignored (1.2.23497) - to serve as a personalised and affectively charged justification for a political decision that has effectively been taken on other grounds already. Thus, with only minor terminological adjustments, the opening sequence of Henry $V$ can seem remarkably like contemporary political analysis in blank verse, and is readily translated. The "spiritual convocation" (1.1.77) whose interests Canterbury represents becomes the German Planungskommitee (planning committee): this change is motivated by the intention to recontextualise the play, but it also neutralises the original's appeal to a

18 Wim Hüsken, 'Mirror, Mirror on the Wall ... History in Late Medieval Drama from the Low Countries', in the present volume, p.20.

19 William Shakespeare, Henry V, in Stephen Greenblatt et al., ed. The Norton Shakespeare (New YorkLondon: W. W. Norton, 1997). Jonathan Dollimore \& Alan Sinfield, "History and Ideology: the instance of Henry V," in Alternative Shakespeares, ed. John Drakakis (London-New York: Methuen, 1985), 215, write that "foreign war was a straightforward ground upon which to establish and celebrate national unity", a ground, however, which "in practice ... was the site of competing interests, material and ideological." On the other hand, Alexander Legatt, Shakespeare's Political Drama: The History Plays and the Roman Plays (London-New York: Routledge, 1988), 122, reports that the motive "to busy giddy minds with foreign quarrels" is "never mentioned" in Henry $V$ - we would argue that it is not very well hidden either. 
divine justification for political hierarchies and military expeditions, the persistent assumption that legitimate power "derives from an inherent natural and human order encoded by God."20

In the Swiss adaptation of Henry $V$, multilingualism becomes the characteristic feature of the local political setting. Shakespeare's play is transplanted to modern, multilingual Switzerland by means of a frame that also inverts the order of Shakespeare's opening scenes. Shakespeare shows the emergence of hostilities at the international level in his first act, and then at the beginning of the second act moves from the political realm of military expeditions to the intensely personal sphere of commoners Nym and Pistol coming to blows: Bardolph attempts to mediate between the two disputants, but their aggression is only laid to rest when Bardolph reminds them that they "must to France together" (2.1.81-82) - the nation and its citizens are now to "task [their] thought / That this fair action may on foot be brought" (1.2.309-10). In the Swiss version, this is the most radically rewritten scene, and is presented before Act I as a Prologue. Bardolph, Nym, Pistol and the Hostess, whose first languages are German, French, Italian and Rumansch respectively, are audience members. ${ }^{21}$ Nym is noisily exchanging angry text messages with Pistol, who is now with his exgirlfriend, the Hostess: Bardolph tries to calm him down to concentrate on the stage performance they have come to watch, but they come to blows, with Bardolph still trying to negotiate peace - while Shakespeare's Bardolph "will bestow a breakfast to make you friends" (2.1.9), Swiss Bardolph offers to invite them for brunch, and is ignored. Bardolph both struggles to appeal to Nym and Pistol in single words of French and Italian (Attends ....Attendi) and tries to convince them by drawing attention to their situation as audience members, or spectators of, rather than actors in, political theatre: "Ihr könnt euch hier nicht schlagen. Die Leute schauen euch zu!” (You can't fight here, people are watching you). Pistol's angry speech to Nym (2.1.40-47) is translated directly from Shakespeare's text into Italian and delivered at furious speed - Shakespeare's language and Italian, less commonly spoken in Switzerland than French or German, here combine to render the lines semantically opaque to most, but, in performance, certainly expressive of anger.

20 Dollimore \& Sinfield, "History and Ideology," 213.

21 We are not the first to place these characters in the audience. Stephen Purcell, "Shakespeare," 147, describes a performance during which they were among the audience during the "Once more unto the breach" speech (3.1.1-34), loudly responding to Henry's call to arms. In that production, however, the characters started out as parts of Shakespeare's historically distant world: we reverse this process, identifying Nym, Bardolph and Pistol as audience members before removing them to the action on stage. 
The scene is interrupted by the arrival of Canterbury and Ely, and focus returns to Bardolph, Nym and Pistol only after the first act has presented the political decision for military action. In a projected news flash, Henry reads out a solemn declaration of war in his most serious and statesmanlike, but also media-adapted, manner. Bardolph, Nym and Pistol comment (rather critically) on Henry's decision to go to war: chillingly, Fluellen then appears on stage, announcing in German, French and Italian that all citizens must report for military service; Bardolph, Nym and Pistol realise that they have changed from spectators into actors. The rewritten scene takes from the original the repeated theme of inter-personal animosity and aggression and the unifying effect of displays of military strength. However, in its modernisation and attempt to set the action in a partly imaginary, but very local, present, it also demonstrates that the worlds of scenes 1.2 and 2.1 depend on and reinforce each other. For every Henry appearing on screen, there is a Fluellen appearing on stage, and every spectator is a potential participant. By presenting the audience with the 'common man' figures of Bardolph, Nym and Pistol first, and the politics second, the Helvetic Henry positions its audience in relation to the action, invoking the ongoing Swiss experience of military conscription as they, too, move from the world of the auditorium to the world of Henry's military campaigns.

In the Swiss adaptation, Henry draws his power not from divine election, but from linguistic skill. The multilingualism of the Swiss adaptation was positively invited by Shakespeare's presentation of Henry as a kind of information nexus in scene 1.2. Henry is a political leader empowered by his ability to gather and exploit information from all sides and, in the Swiss version, in all languages. Staging Swiss Canterbury as a (secularised) external advisor who makes a bilingual, German-French meeting presentation, complete with confusing powerpoint, and Henry's entourage as ministers and representatives of various parts of the country, each speaking their own language, reinforces the image of Henry as the polyglot personification of authority, a controlling centre of the multitude of voices which make up his environment. During the Salic law speech, the original form of which might present "two perfectly clear arguments" which, however, are "so overlaid with incidental detail that it sounds confusing," 22 Henry himself takes on the role of an interested audience for a presentation further obfuscated by Canterbury's code-switches among German, French and Swiss-German dialects, and by textual alterations which, at times, might tip the speech into parody. Canterbury rattles

22 Legatt, Shakespeare's Political Drama, 121 (emphasis in the original). 
through a list of paragraph numbers, accompanied by slides providing increasingly obscure and irrelevant glosses - for example, one slide declares:

section 9, sub-section 2 of an old German customs-union treaty was itself engendered by aversion to section 13, number 2, point 3 of female-hotel-workers' regulations. The term 'female-hotel-workers' is taken to include all women regularly employed in restaurants, bars, coffee-shops, fast-food joints, ice-cream vans or any similar businesses under a commonly accepted understanding of the word 'similar' or synonyms thereof.

Canterbury's speech itself is full of stylistically impossible (but neatly iambic) German compounds such as die Gastgewerbsarbeiterinnenordnung: however, it is certainly plausible that a Swiss speaker presenting various parts of an argument, even in a relatively formal, internal meeting, might make some of his points in French and others in German, and then close with a final statement in Swiss-German dialect. As the speech's on-stage addressee, Henry is expected to be able to take everything in, or, perhaps, to unveil the practical consequences of the linguistic avalanche unleashed by his interlocutor - and here he becomes the kind of expert-audience who knows what they are supposed to understand in detail and what they can safely ignore. When he eventually interrupts with a simple question: "Kann ich mit Fug und Recht Anspruch erheben?" (May I with right and conscience make this claim? [1.2.96]), he directs Canterbury to get to the point and offer one clear statement of legitimisation for a clearly favoured political project. Canterbury responds in clear, intelligible German. Henry knows his job, which, in this instance, is to hear and understand precisely as much as he needs to, precisely when it is necessary.

Henry's eloquence and rhetorical genius - or, in less admiring terms, his skilful manipulation of his own discursive appearance - have often been discussed. ${ }^{23}$ Again, the multilingual adaptation is an invitation to take literally the suggestion that Canterbury's praise of Henry in the first scene (1.1.39-60) is directed as much at his mastery of a wide array of linguistic registers as at his overall wisdom and practical competence. The Swiss adaptation reinforces the construction of Henry as the multilingual image of national unity, in whom all linguistic differences are taken up and merged

23 See, for instance, ibid., 126-27, or, for an investigation of some twentieth-century appropriations and reactions to the powerful buy worryingly bellicose rhetorical power of Shakespeare's text, Ton Hoenselaars, "Shooting the Hero: The cinematic career of Henry V from Laurence Olivier to Philip Purser," in World-wide Shakespeares, ed. Massai (London-New York: Routledge, 2005), 80-87. 
into one, by dividing Canterbury's speech in praise of Henry between Canterbury and Ely: the two praise Henry in turn, one speaking French, the other German: they are brought into a bilingual dialogue by the common theme of Henry's almost superhuman omniscience and omnipotence:

\author{
Ely: $\quad$ Orientez-le sur n'importe quel sujet politique, \\ Et il en dénouera le nœud gordien \\ Aussi facilement qu'une jarretière \\ Canterbury:Und wenn er spricht \\ Hält selbst die Luft in ihrem Treiben inne, \\ Und stummes Staunen steckt in allen Ohren, \\ Um was er sagt wie Honig aufzusaugen. ${ }^{24}$
}

[Ely: Turn him to any cause of policy. The Gordian knot of it he will unloose, familiar as his garter

Canterbury: that, when he speaks, the air, a charter'd libertine, is still, and the mute wonder lurketh in men's ears, to steal his sweet and honey'd sentences. (Henry VI.1 45-51)]

They need Henry, as a political agent for the implementation of their own agenda, and to unite their linguistically divided discourse into a coherent statement of nationality and policy.

The explicitly re-contextualising Swiss adaptation, however, develops more fully hints in Shakespeare's text that Henry's political power might in fact be rather shallow. ${ }^{25}$ Henry's invitation to Canterbury to present his argument for military action, which offers the first of the play's many explicit renderings of the horrors of war (1.2.9-32), can also be read as a slick, rhetorically stream-lined statement prepared for media consumption, a token declaration of Henry's commitment to righteousness and humanity which in fact transfers responsibility for the consequences of the later decision onto Canterbury and other, less public figures. ${ }^{26}$ In the Swiss adaptation, then, this speech exemplifies political theatre's pre-emptive disavowal of responsibility, as it is directed in statesmanlike posture to a group of journalists and rolling cameras. When Henry directs Canterbury "Under this conjuration, speak, my lord" (1.2.29), this is rendered in German: "Jetzt sind Sie eingeschworen, sprechen Sie" (Now you are sworn

24 Compare Henry V, 1.1.45-51.

25 And it can find more textual support in the original. Henry's speech at 4.1.212-66, lamenting the hardships of his position, can be read as questioning the extent of Henry's real power to shape his own fortune (see Dollimore \& Sinfield, "History and Ideology," 222-23).

26 The notion that Henry is "touchy on the question of responsibility, always trying to shift the burden" is also found in Legatt, Shakespeare's Political Drama, 133. 
in, speak), suggesting a curt handling of official formalities before a political hearing which, set in a context of power politics, challenges a critical audience to expect some degree of insincerity.

This simultaneously 'modernises' the figure of Henry and makes him less powerful. He publicly transfers responsibility to Canterbury, but thereby partly denies his own power of decision. The scene of deliberation becomes a ritualised information gathering on the part of stately dignitaries, skilfully shaped to ensure that nobody will end up looking truly and fully responsible: this emphasises the extent to which, in Alexander Legatt's words, Henry is aware that "his principal task is not the arrangement of his soldiers on the field [or, indeed, deciding whether to arrange them at all] but the preparation of their minds"27 - his task, whether it be rousing his troops, identifying and punishing traitors, or interacting with the enemy, is executive rather than legislative; it concerns the implementation of policies, not their formulation. Swiss Shakespeare took a similar approach to Henry's infamous order to kill the French prisoners: in this version it is in fact Canterbury who decides the action and first orders, "Dann soll jeder seine Gefangn'nen töten" (Then every soldier kill his prisoners): Henry merely commands that the order be disseminated: "Gebt den Befehl" (Give the word through). This in no way exonerates Henry, though it might make clear that responsibility is shared; at the same time, it demonstrates that for all his linguistic prowess, Henry's political power is limited.

\section{$4 \quad$ Constructing the Enemy}

A particular problem for Helvetic Henry was the identity and nature of the enemy. Once Henry is taken out of his historical religious, monarchical, national context, it is no longer obvious who could be particularised as his foe. A solution to this difficulty was found in the nature of Shakespeare's presentation of the French army, which is highly parodic and appears to draw on national stereotypes of French vanity, for example. Arguably, Shakespeare presents the French through the eyes of the English: they are the enemy as imagined, rather than as actually encountered. The Helvetic Henry pushed this idea to the extreme by implying that the enemy was in fact purely a product of the collective imagination of the play's characters, their fears stoked and fed by Henry's skilful rhetoric, to his own political ends. Thus, scenes of negotiation with the French Dauphin, for example, 
were ventriloquised by Bardolph, Nym and Pistol who, in order to pass the time in the military camp, made sock puppets and imagined the negotiations of their political masters:

Bardolph: Der Botschafter fordert Henry auf, sich zu ergeben. Ich weiss, wie das aussieht:

(als Botschafter) Mein Befehlshaber sagt: Sag du dem grossen Henry: Auch wenn es schien, dass wir tot sind, wir haben nur geschlafen $\cdots$

Nim: $\quad$ Henry répond:

(als Henry) Retourne sur tes pas,

Et dit a ton maitre que je ne le cherche pas encore. ${ }^{28}$

[Bardolph: The ambassador asks Henry to surrender. I know what that looks like: (As ambassador) Thus says my leader: Say thou to Harry the Great: Though we seemed dead, we did but sleep ... Nim: To which Henry responds: (as Henry) Turn thee back, And tell thy master I don't seek him now.]

When Gower, who in the Swiss adaptation has become an embedded journalist, needs images of the enemy lines, he trains the audience also to hold up sock puppets and shout aggressively. These sock puppets are then 'slaughtered' by Bardolph, Nym and Pistol using camp cutlery in parodic versions of Shakespeare's battle scenes: the audience were thus reminded of the relevance to them of the power play presented while also provoked to laughter which rendered absurd the rhetoric - sometimes violent, sometimes stirring - with which Henry surrounded the play's battles. ${ }^{29}$ Where they were threatened with infants spitted on pikes, the audience saw sock puppets thrown to the floor, and the expected valour of the "happy few' was nothing more than men facing dirty laundry. In this setting, Henry's vigorous and celebrated speeches made him appear ridiculous and far removed from the audience, who were enthusiastically participating not in a battle but in a game. Importantly, however, Bardolph, Nym and Pistol were slaughtering the enemy in earnest: they were in the world of Henry's rhetoric, not the sock puppet game. The scene demonstrated the dangerous power of skilful politicians to manipulate people's fears in order to create an exaggerated imagining of an enemy, and then send an army to fight a real war.

28 Compare Henry V, 3.6.87-88 and 111-12.

29 Elsa Strietman's essay in the present volume draws attention to the common practice, in adapting a historical text, of adding comical elements that are also often rather dark, and may be used to expose the horrors of war. 


\section{Custom and Kissing}

In the final scene of Shakespeare's play, Henry stages a political reconciliation by wooing the daughter of the enemy's leader. The diplomatic settlement on which the ritual depends has already been prepared and is now being finalised off-stage by negotiators who have

... free power to ratify,

Augment or alter...

Anything in or out of our demands (5.2.86-89) 30

Therefore, no real political power is employed in the making of the onstage scene, although the scene demonstrates a fresh aspect of the relationship between language and power in dialogue; the power that Henry gains from non-understanding. This is related to Henry's ability, foregrounded in the Helvetic Henry, to know exactly how much to understand of Canterbury's explanation of Salic Law: responsibility is passed to the interlocutor Canterbury, or here Katherine - and thus abdicated by Henry. Henry claims not to speak French: the onus is at first on Katherine to speak English. Katherine has been preparing for this moment, studying English by learning the names of body parts from her lady in waiting, Alice. If the naming of body parts does not seem the highest priority in language for international diplomacy, we are reminded of course of the symbolism of the king's two bodies, and furthermore that Katherine's diplomatic role is simply to hand over her body to Henry in marriage. The scene is the most celebrated multilingual moment in Shakespeare's work; it depends on the enduring appeal of the interlingual pun, the schoolboy delight that a word quite innocent in one language can sound smutty in another. The Swiss translators therefore built their scene around appropriate equivalent puns, first producing a list of words to do with bodies and clothing that could be obscenely translated, and with the advantage over Shakespeare that their puns could be German, French or Italian, since their Katherine was an English speaker learning 'Swiss'. The list prepared, the translators could then follow the structure of the Shakespearean scene, translating Shakespeare's French into English (in Alice's case English with occasional errors, to signal that she is a native German speaker) and substituting

30 Katherine Eisaman Maus ("Introduction" to Henry V, in Greenblatt et al., The Norton Shakespeare, 1451) calls this scene "quite endearing onstage" but also "entirely beside the point". 
Shakespearean 'double entendres' for 'triple entendres' made available by the multilingual setting of the play. For example, having learned that one of the languages of Switzerland is Italian, Katherine asks the Italian for 'head' and 'clothing':
Alice: $\quad$ 'Testa', madam, and 'vestiti'.
Katherine: Testi ... and Vest titties. Oh my God! These words sound ugly, venal,
barbarian and lewd, and are not to be used by ladies of class: I wouldn't pronounce these words in front of important men for all the world. ${ }^{31}$

However, Katherine's practice at the naming of parts is not the best preparation for her subsequent scene with Henry, who, in Shakespeare's original, addresses her not only in English but also in a string of conceits and puns that at first cause her to distrust him and declare "les langues des hommes" (the tongues of men) to be "pleines de tromperies" (full of deceits; 5.2.115-16). Intriguingly, the comment seems to indicate that Katherine does in fact comprehend not only English but also Henry's conceits and the deeper intention of them: though Henry and Katherine both assert their lack of proficiency in each other's tongues, they seem also to understand each other perfectly. Henry first asserts that he lacks facility not in French but in the language of love - he could win a woman "at leap-frog" yet "cannot look greenly, nor gasp out ... eloquence" (5.2.135-41). When he finally addresses Katherine in French, his speech is not of love but of possession - language which, though it could sound romantic, seems more a surprisingly frank revelation of Henry's priorities - and is both direct and logical: "Je quand suis le possesseur de France, et quand vous avez le possession de moi . . . donc vôtre est France, et vous êtes mienne" (5.2.17275). ${ }^{32}$ It is ironic, of course, that Henry, the master rhetorician, asserts that it is easier for him to win a woman through actions than words, and his wooing scene is as fine a display of rhetorical persuasion as any. Finally, Henry asserts a mutuality - Katherine will possess France and him as he possesses France and her - but the gain is always on the English side:

\footnotetext{
Compare Henry V, 23.3.46-52.

32 According to Gary Taylor, the word order 'Je quand suis' would have been acceptable French, but seems unidiomatic now and might well have seemed so to earlier audiences: 'When I am the possessor of France, and when you have possession of me, then France is yours, and you are mine.' See William Shakespeare, Henry V, ed. Gary Taylor, 273 n.176.
} 
discussing their future heir, he declares: "Kate, you will endeavour for your French part of such a boy, and for my English moiety take the word of a King" (5.2.200-02). Moiety is loaned from French ${ }^{33}$ but of course never given back.

Nonetheless, Henry announces his intention to operate through actions rather than words and kiss her. Katherine's response, in French, that it is not the custom for women in France to kiss before they are married, makes an important point for theatrical translation: manners are a culturally variable code, like language, and thus need to be translated as much as words. Henry has no time for local custom, arguing his royal right to make manners. Nonetheless, the theme of national codes of kissing seems to have struck a chord with Shakespeare's contemporaries; ${ }^{34}$ this scene from Henry $V$ is echoed in a scene of Alphonsus, Emperor of Germany, a play that pushes the potential of the macaronic text, this time GermanEnglish, much further than Shakespeare's Henry V. Prince Edward, meeting the German princess Hedewick whom he intends to woo, kisses her, and she exclaims: "See dodh, dass ist hier kein gebranch, / Mein Got ist dass dir Englisch manier, dass dich". ${ }^{35}$ Although the Emperor explains that "here in Germany / To kiss a Maid" is "a fault intollerable", Edward refuses to acknowledge national differences: "Why should not German Maids be kist aswell / as others?", "I am an Englishman, why should I not?". Edward's uncle tries to manage the situation through words:

... because you did not know the fashion And want the language to excuse your self I'l be your spokes-man to your Emperess.

33 The English word comes from Old French moite, which also gives the modern French moitié. See https://www.etymonline.com/word/moiety.

34 For an intriguing reading of a rather different kiss, between two decapitated heads, that depends on "the legibility of the kiss as a signifier of social and political power", see Kellie Robertson, "The Rebel Kiss: Jack Cade, Shakespeare, and the Chroniclers," in Renaissance Retrospections: Tudor Views of the Middle Ages, ed. Sarah A. Kelen (Kalamazoo: Medieval Institute Publications, 2013), 132.

35 The German is inaccurate and nonsensical, but seems to have been intended to mean something like: "See here, that is not the custom here. My God, is that the English way, that you do." The errors are possibly introduced by the typesetter: for example, 'gebranch' is created by a misinterpretation of the minims in 'gebrauch'. In the printed edition of 1654, the German lines are in rather smudged blackletter which is difficult to read. George Chapman, Alphonsus, Emperor of Germany, ed. Herbert F. Schwarz. (South Yarra: Leopold Classic Library, 2015 [rpt. in facsimile from the edition of 1654]) act 2, scene 1, 14 . 
but Edward, like Henry, asserts his preference for deeds in "English Courtship": "I'l prove it with my Sword". ${ }^{36}$

Our Helvetic Henry foregrounds Henry's lack of political power, his absurd avowal of actions over words, his linguistic colonization of Katherine, his disregard of custom; however, since we have signalled Henry's verbal power through his multilingual abilities, this scene requires a different device, not simply that Henry does not understand Katherine's language. The final scene of Shakespeare's play is presented in the Swiss adaptation as a further scene-within-a-scene - a puppet show staged for the surviving characters. This emphasises the potential of military power-play to be retrospectively overlaid by a symbolism of sexualised 'conquest', and indeed of war to become retrospectively 'domesticated'. The scene has a deceptive appearance of light-hearted playfulness. While Chapman's Alphonsus reframes motifs from Henry $V$ in a different register and thereby functions as a literary comment on Shakespeare's text, our staging of the scene locates Henry outside his own play, watching a comical performance that, though staged to celebrate his power, holds the mirror up to him in a different role, turning history into a spectacle with its eponymous hero as a mere spectator. Shakespeare has Henry ostentatiously struggling to play the lover as it is not his usual role: whereas Shakespeare's Henry incorporates this difficulty into his rhetoric, the Swiss Henry must passively watch his puppet-avatar clumsily enact rituals of sexual conquest, his power taken out of history and reduced to code-switching, words uttered by puppeteers without deeds.

\section{Conclusion}

The $600^{\text {th }}$ Anniversary of Agincourt was also, in an interesting historical coincidence, the 500th Anniversary of the Battle of Marignano. In 1515 the Swiss fought one of the most significant battles of their history against the French: their crushing defeat by the French led the Swiss to sign the Treaty of Fribourg, which achieved a 'Perpetual Peace' with France that, apart from a brief Napoleonic incursion, has been sustained. Marignano is seen as the beginning of Swiss neutrality, and was marked by commemorative ceremonies in Fribourg in 2015. It might have been possible, instead of creating Helvetic Henry, for the Fribourg-based Swiss Stage Bards to devise

36 George Chapman, Alphonsus, Emperor of Germany, reprinted in facsimile from the edition of 1654, with an introduction and notes by Herbert F. Schwarz (New York-London: The Knickerbocker Press, 1913), act 2 , scene $1,17-18$. 
a play that celebrated, in Switzerland, a moment of Swiss history. But the ostensibly rather perverse desire to instead adapt the alien history of an ambiguously heroic king, as told by the literary star of a foreign nation, presented a creative challenge that bore sometimes surprising fruit. The process of translation led to an inherent but also thematic focus on the role of languages and language in causing political events, interpreting their significance, and creating and staging a national history.

\section{Acknowledgements}

I would like to acknowledge the contribution to this article of Thomas Aeppli, with whom much of this material was prepared for presentation at the European Shakespeare Research Association conference in Gdansk, 2017. I am indebted to the Swiss Stage Bards, and especially the Producer of their Henry V, Alina Willi, to Raphael Berthele, and to the translators of Swiss Shakespeare: Thomas Aeppli, Aurélie Blanc, and Elisa Pagliaro.

\section{Bibliography}

Déprats, Jean-Michel. "A French history of Henry V." In Shakespeare's History Plays: Performance, Translation, and Adaptation in Britain and Abroad, edited by Ton Hoenselaars, 75-91. Cambridge: Cambridge University Press, 2004.

Dollimore, Jonathan \& Alan Sinfield. "History and Ideology: the instance of Henry V." In Alternative Shakespeares, edited by John Drakakis, 206-27. London-New York: Methuen, 1985.

Donaldson, Peter S. "Taking on Shakespeare: Kenneth Branagh's Henry V." Shakespeare Quarterly 42 (1991): 60-71.

Erne, Lukas. "Lamentable comedy or black tragedy?: Friedrich Dürrenmatt's adaptation of Titus Andronicus." In World-wide Shakespeares: Local appropriations in film and performance, edited by Sonia Massai, 88-94. London-New York: Routledge, 2005.

Greenblatt, Stephen et al., ed. The Norton Shakespeare. New York-London: W. W. Norton, 1997.

Hindle, Maurice. Studying Shakespeare on Film. Basingstoke: Palgrave Macmillan, 2007.

Hoenselaars, Ton. "Shooting the Hero: The cinematic career of Henry V from Laurence Olivier to Philip Purser." In World-wide Shakespeares, edited by Massai, 80-87. London-New York: Routledge, 2005.

Legatt, Alexander. Shakespeare's Political Drama: The History Plays and the Roman Plays. London-New York: Routledge, 1988. 
Purcell, Stephen. "Shakespeare, Spectatorship, and the 'Olympic Spirit'." In Shakespeare on the Global Stage: Performance and Festivity in the Olympic Year, edited by Paul Prescott \& Eric Sullivan, 133-62. London: Bloomsbury Arden Shakespeare, 2015.

Robertson, Kellie. "The Rebel Kiss: Jack Cade, Shakespeare, and the Chroniclers." In Renaissance Retrospections: Tudor Views of the Middle Ages, edited by Sarah A. Kelen, 127-40. Kalamazoo: Medieval Institute Publications, 2013.

Rokison, Abigail. "'From thence to England': Henry $V$ at Shakespeare's Globe." In Shakespeare Beyond English: A Global Experiment, edited by Susan Bennett \& Christie Carson, 303-07. Cambridge: Cambridge University Press, 2013.

Shakespeare, William. Henry V, edited by Gary Taylor. Oxford: Clarendon Press, 1982.

Steinsaltz, David. "The Politics of French Language in Shakespeare's History Plays." Studies in English Literature 1500-1900 42 (2002): 317-34. 